\title{
De rol van begrijpelijke taal in een digitale context Ontwikkelingen op de domeinen Leven Lang Leren, complexe financiële producten, bestuur en politiek, en gezondheid
}

\section{Inleiding}

Burgers kiezen. ${ }^{1}$ Tussen een avondje uit of het volgen van een cursus, tussen een spaarhypotheek of een aflossingsvrije beleggingshypotheek, tussen de VVD of Groen Links, tussen een hamburger of een salade. Die keuzes kunnen verstrekkende gevolgen hebben voor hun deelname aan de maatschappij. Ze beïnvloeden hun positie op de arbeidsmarkt, financiële situatie, het overheidsbeleid en hun gezondheid. Gegeven de mogelijke verstrekkendheid van de gevolgen is het belangrijk dat burgers een beredeneerde keuze kunnen maken. Accurate, relevante en begrijpelijke informatie is daarbij van groot belang.

De toenemende digitalisering van informatie, de opkomst van het World Wide Web en de explosieve groei van sociale media hebben grote gevolgen voor zowel het aanbod en de presentatie van informatie als de manier waarop mensen informatie zoeken en gebruiken. In dit onderzoek proberen we deze ontwikkelingen in kaart te brengen voor vier maatschappelijke domeinen: leven lang leren, complexe financiële producten, bestuur en politiek, en gezondheid. Deze domeinen vormen verschillende arena's waarin de burger in de slag gaat met andere

\section{Samenvatting}

Burgers krijgen in toenemende mate de verantwoordelijkheid voor hun eigen welvaren toebedeeld. Voor het nemen van die verantwoordelijkheid moeten ze kunnen beschikken over accurate, relevante en begrijpelijke informatie. De digitale revolutie heeft geleid tot grote veranderingen in de omvang en vorm van informatievoorziening. Om de toekomstige ontwikkelingen en de rol van begrijpelijke taal bij die informatievoorziening in kaart te brengen, zijn interviews gehouden met informanten uit verschillende domeinen. Daarbij kwamen de volgende hoofdlijnen naar voren. De enorme toename van het informatieaanbod vergroot de kans dat er relevante informatie beschikbaar is, maar verkleint de kans om die daadwerkelijk te vinden. Behalve onbegrijpelijke taal vormt ook het gebrek aan motivatie een probleem. Daarnaast is er nog te weinig kennis over hoe verschillende modaliteiten het beste gecombineerd kunnen worden voor een optimale informatievoorziening. Juist die kennis zou van belang zijn om nu moeilijk te bereiken groepen op optimale wijze te informeren. 


\section{De rol van begrijpelijke taal in een digitale context}

spelers. Soms lijken de belangen van die spelers parallel te lopen zoals bij medici die mensen informeren over hun gezondheid, soms zijn die belangen in potentie tegenstrijdig zoals in het geval van financiële dienstverleners die zo veel mogelijk winst willen behalen op het product dat ze aanbieden. Soms is er een scheidsrechter aanwezig (bijvoorbeeld de Autoriteit Financiële Markten), maar soms ook niet.

De selectie van deze domeinen is ingegeven door het feit dat het hier gaat om vier domeinen die een grote invloed hebben op persoonlijke, sociale en professionele participatie in de maatschappij.Voor elk domein geldt dat er complexe informatie beschikbaar is waarbij het erg belangrijk is dat de burgers de informatie begrijpen om de consequenties van hun keuzes goed te kunnen overzien en/of de informatie goed toe te kunnen passen in voor hen relevante 'levensgebeurtenissen'. Met de razendsnelle ontwikkelingen op allerlei terreinen moeten werknemers steeds bijleren om hun waarde voor werkgevers te versterken of op zijn minst te behouden. De problemen met de DSB bank en woekerpolissen hebben duidelijk gemaakt welke desastreuze gevolgen het aanbieden van ondoorzichtige financiële producten kan hebben voor zowel klant als aanbieder. In de relatie tussen overheid en burger, is het belangrijk dat de ogenschijnlijk groeiende kloof tussen beide partijen wordt gedicht en de dienstverlening aan de burger zo effectief en efficiënt mogelijk wordt afgehandeld. En in verband met kostenbeheersing in de zorg, is het van belang dat mensen zo lang mogelijk gezond blijven. Bij deze vier domeinen spelen dus zowel individuele als maatschappelijke belangen een rol.

Bij het in kaart brengen van de gevolgen van de digitale ontwikkelingen voor het informatieaanbod en -gebruik in deze domeinen zijn we in eerste instantie niet uitgegaan van de wetenschappelijke literatuur. De ontwikkelingen in de praktijk gaan sneller dan het onderzoek naar deze ontwikkelingen. We hebben er daarom voor gekozen om per domein belangrijke spelers in kaart te brengen en een aantal van hen te interviewen om hun visie op de huidige situatie en toekomstige ontwikkelingen in kaart te brengen.

Deze opzet heeft geleid tot de volgende structuur van dit artikel. Elke verkenning wordt beschreven in een aparte paragraaf (paragrafen $2 \mathrm{t} / \mathrm{m} \mathrm{5}$ ). De opbouw van deze paragrafen is identiek. Elke paragraaf begint met een kort overzicht van het domein, gevolgd door een beschrijving van de gehanteerde methode, de resultaten van de interviews en ten slotte worden de implicaties voor de rol van begrijpelijke taal voor het desbetreffende domein belicht. In paragraaf 6 , ten slotte, gaan we in op de meer algemene trends die uit deze verkenningen naar boven komen en de implicaties voor toekomstig onderzoek.

\section{De burger als eeuwige student: Leven Lang Leven}

Het Europese beleid op het terrein van Life Long Learning (LLL) bestrijkt een breder gebied dan het Nederlandse. In Europa richt men zich op onderwijs "van de wieg tot het graf" (Commission of the European Communities, 2000) en daarmee op het hele traject van primair onderwijs tot volwasseneneducatie. In Nederland ligt de nadruk veel meer op het op peil houden en verbeteren van de competenties van de beroepsbevolking. De doelgroep wordt gevormd door werkgevers, werknemers en werkzoekenden. De achterliggende motivatie is economisch van aard. Als Nederlanders hun reguliere opleiding bij een onderwijsinstelling afsluiten, zijn ze relatief jong: afhankelijk van de opleiding komt het grootste deel tussen hun $16^{\mathrm{e}}$ en $25^{\mathrm{e}}$ op de arbeidsmarkt. In het gunstigste geval zijn deze mensen vervol- 
gens ruim 40 tot 50 jaar actief op die arbeidsmarkt. Hoe goed geëquipeerd ze ook zijn op het moment dat ze hun opleiding afronden, de ontwikkelingen die zich op allerlei werkvelden voordoen leiden ertoe dat ze zich gedurende die periode nieuwe kennis en vaardigheden eigen zullen moeten maken om waardevol en productief te blijven voor hun werkgever.

In Nederland is men bezig met het ontwikkelen van een kader (het NLQF: Netherlands Qualification Framework) waarin de kwalificaties van de Nederlandse beroepsbevolking in kaart worden gebracht. In dit kader wordt natuurlijk aandacht besteed aan de resultaten van het zogenaamde 'formeel leren': het volgen van onderwijs aan erkende onderwijsinstellingen (zoals een $\mathrm{MBO}$-opleiding of een universiteit) wat bij een succesvolle afsluiting resulteert in een diploma. Maar het kwalificatiekader beoogt ook de kwalificaties als gevolg van non-formeel en informeel leren te beschrijven. 'Non-formeel' leren bestaat uit het volgen van trainingen of cursussen, binnen of buiten het werk, die door de organisatie zelf, maar ook door daarin gespecialiseerde bureaus worden aangeboden. Ten slotte spreekt men over 'informeel leren': dit verwijst naar het verwerven van competenties, in bijvoorbeeld alledaagse situaties, zonder dat het individu zich die verwerving tot doel heeft gesteld (Commission of the European Communities, 2000, p. 8).

In deze verkenning hebben we ons vooral gericht op de gevolgen van digitalisering voor LLL met als doelgroep de Nederlandse beroepsbevolking in de leeftijd van grofweg 25 tot 65 jaar. De technologische ontwikkelingen sluiten met name aan bij de situatie waarin de LLL-doelgroep zich bevindt én bij de eigenschappen van het leerproces. Het gaat immers voor een belangrijk deel om mensen die werk en leren moeten combineren. Door het digitale aanbod is het voor hen mogelijk om ook (en misschien wel: juist) buiten kantooruren en schoolmuren de benodigde competenties te verwerven. Daarnaast vormt het grote aanbod op (mobiel) internet een sterke stimulans voor het informele leren. Tevens biedt dat aanbod de mogelijkheid tot zelfsturing, een ander belangrijk kenmerk van LLL (Theunissen, 2009). Ten slotte zijn digitale toepassingen zoals 'serious games' bij uitstek competentieverwervingsgericht.

Een tweede overweging is dat bovenstaande ontwikkelingen in een LLL-context sneller en breder worden toegepast. Serious games, maar ook rollenspelen worden veel meer ingezet door bedrijven dan door het reguliere onderwijs. Met name het afstandsonderwijs, dat zich van oudsher vooral richt op volwassenenonderwijs, is een voedingsbodem voor veel van deze nieuwe ontwikkelingen (Barbour \& Reeves, 2009). Sommige van deze ontwikkelingen zullen (uiteindelijk) ook in het reguliere onderwijs worden ingezet. Omdat het doel van deze verkenning echter is om zo ver mogelijk in de toekomst te kijken, hebben we ons vooral gericht op die context waarin zich de nieuwste ontwikkelingen voordoen.

2.1 Methode Om een goed beeld te krijgen van de toekomstige ontwikkelingen zijn er negen interviews gevoerd met informanten die actief zijn op verschillende aan LLL gelieerde terreinen. Voor wat betreft het Nederlandse beleid zijn er interviews gehouden met ambtenaren van het ministerie van Onderwijs, Cultuur en Wetenschappen en de voormalig voorzitter van de adviescommissie 'Leven Lang Leren'. Daarnaast zijn er gesprekken gevoerd met vertegenwoordigers van de Open Universiteit, een organisatie die bedrijfstrainingen verzorgt, een ontwikkelaar van serious games en het voormalige TELEAC. Ten slotte is ook een aantal onderzoekers geïnterviewd. Voor sommige onderzoekers geldt dat ze in dienst zijn van onderwijsaanbieders, voor anderen geldt dat ze als onderzoeker verbonden zijn aan de universiteit of hogeschool. 


\section{De rol van begrijpelijke taal in een digitale context}

De interviews kenden de volgende opzet. Het eerste thema had betrekking op de gevolgen van digitalisering voor LLL. De openingsvraag luidde:"Welke mogelijkheden bieden de technologisch ontwikkelingen voor leven lang leren en hoe ziet u de toekomst wat dat betreft?" In de eerste interviews werd dit thema gevolgd door de vraag naar de rol die (begrijpelijke) taal in de toekomst zou spelen bij die overdracht. Het bleek dat informanten enthousiast vertelden over de toekomstige ontwikkelingen maar stilvielen bij de vraag naar de rol van begrijpelijke taal. Dit leek geen thema dat nadrukkelijk figureerde in hun toekomstvisie. Daarom is er voor gekozen om niet naar de rol van "taal" te vragen, maar naar hun ideeën over hoe de interface met de leerder er in de toekomst uit zou zien. Dit bleek voor de informanten een gemakkelijker te beantwoorden vraag die bovendien inzicht gaf in de rol die taal speelt in relatie tot andere modaliteiten. Ten slotte werd gevraagd of er in de ogen van de informant verschillende doelgroepen waren die gemakkelijker of moeilijker met het interface om zouden kunnen gaan. Als de informant niet zelf met voorbeelden kwam, gaf de interviewer voorbeelden als laaggeletterden of mensen met een andere moedertaal dan het Nederlands. Die insteek leverde een beter zicht op de rol die begrijpelijke taal bij LLL kan spelen.

De transcripten van de interviews vormden de basis voor de analyse. Per thema werd bepaald welk beeld in de interviews naar voren kwam. Vervolgens werd onderzocht in hoeverre die beelden overeenkwamen dan wel verschilden van elkaar. Uit de analyse kwamen geen tegenstrijdige visies naar voren. De interviews vulden elkaar over het algemeen aan. Hieronder worden de belangrijkste resultaten beschreven. Het conceptrapport over de verkenning van dit domein werd ter controle aan de informanten voorgelegd. De informanten herkenden zich in het geschetste beeld. Deze procedure is in grote lijnen ook bij de andere drie verkenningen gehanteerd.

2.2 Resultaten Een belangrijke ontwikkeling is de (enorme) toename van het aanbod aan informatiebronnen, de zogenaamde Open Educational Resources (OER). Steeds meer onderwijsmodules, maar ook video-opnames van colleges en dergelijke zijn gratis beschikbaar via het Internet. Op wereldniveau zet de UNESCO zich in voor de verdere uitbreiding van dergelijke OERs vanuit het idee dat mensen op die manier het beste onderwijsmateriaal uit het internationale aanbod kunnen selecteren. Dat aanbod beperkt zich niet tot (standaard) onderwijsbronnen zoals literatuur en colleges, maar omvat ook serious games en augmented learning. In serious games 'spelen' gebruikers een interactief spel dat niet zozeer ontspanning wil bieden maar gebruikers in staat stelt om in een veilige omgeving de consequenties van hun keuzes te ervaren en daarmee nieuwe vaardigheden op te doen. Bij augmented learning worden virtuele data geprojecteerd op objecten in de werkelijkheid om zo een augmented reality te creëren. Hierdoor kunnen studenten Geschiedenis of Archeologie visuele simulaties van verwoeste gebouwen of steden "zien" en kunnen studenten Geneeskunde de werking van het menselijk lichaam van binnenuit bestuderen.

$\mathrm{Nu}$ steeds meer mensen beschikken over een smartphone, netbook of tablet wordt het steeds gemakkelijker om die informatie op elk gewenst moment en op elk gewenste plaats te consulteren. Zeker voor augmented learning biedt dat goede mogelijkheden. Lopend door een vreemde stad krijgt de gebruiker aanvullende informatie over gebouwen, diensten en evenementen aangeboden waardoor het zogenaamde 'leren in context' kan plaatsvinden. Deze communicatiemiddelen maken het niet alleen mogelijk om onderwijsinhoud te downloaden, maar ook om via sociale media contact te leggen en te houden met gelijk- 
gestemden. Door het leren in context en het gebruik van sociale media zal de relatie tussen docent en lerende, en tussen lerenden onderling veranderen.Verschillende informanten verwachten dat dit zal leiden tot een leerproces waarbij deelnemers vooral van elkaar leren. Net zoals sociale netwerken worden gebruikt om informatie uit te wisselen over de kwaliteit van restaurants, het oplossen van computerproblemen of het omgaan met producten, zouden deelnemers via deze media vooral 'best practices' uitwisselen. De docent vervult dan eerder de rol van coach of kennismakelaar dan die van centrale informatie- en instructiebron.

De interface zal in toenemende mate multimodaal van aard zijn. Dat wil zeggen dat de informatie niet alleen in de vorm van (geschreven) taal wordt aangeboden, maar dat ook audio, (bewegend) beeld en video's worden ingezet om de informatie over te dragen. Burgers zijn gewend aan professioneel vormgegeven commerciële websites die hun zintuigen behagen. Onderwijsomgevingen die daar op een vergelijkbare manier in slagen, hebben een grotere kans om gebruikt te worden. Met name voor serious games is het van belang om de zintuigen van de gebruiker te bespelen. Naarmate de game meer zintuigen aanspreekt, neemt de subjectieve realiteit van de virtuele wereld toe waardoor de leerervaring meer zal beklijven zo stellen ontwikkelaars van deze games. Een van de informanten noemt dit de "flow" ervaring die een game probeert op te wekken bij de gebruiker. Ten slotte wordt de verwachting uitgesproken dat de interface een menselijk gezicht krijgt in de vorm van een digitaal gecreëerd personage dat dienst doet als coach of docent.

Naast multimodaliteit wordt adaptiviteit als belangrijk kenmerk van het nieuwe onderwijsaanbod gezien. Verschillende informanten wijzen op de mogelijkheid van tailoring, het toesnijden van de inhoud en van de vorm op de individuele kenmerken van de gebruiker waardoor de relevantie en begrijpelijkheid van de informatie kan worden vergroot. Daarbij worden persoonskenmerken (sekse, leeftijd, intelligentie en cultuur), ervaring (opleiding, werk- of praktijkervaring, levenservaring) en leervoorkeuren (persoonlijke leerstijlen, leerstrategieën en leerdoelen) genoemd (Theunissen, 2009). Daarnaast bieden digitale toepassingen de mogelijkheid om gebruikers direct feedback te geven op hun prestaties en keuzes. Voor een goede transfer van de onderwijscontext naar de werkomgeving is het daarbij belangrijk dat de gebruiker reflecteert op de relevantie van de opgedane kennis en ervaring voor de eigen werkcontext.

Dat het aanbod groeit, betekent niet automatisch dat er ook meer gebruik van wordt gemaakt. Lager opgeleide mensen lijken meer gemotiveerd te moeten worden om gebruik te maken van de mogelijkheden (Van Merriënboer, Kirschner, Paas, Sloep \& Caniëls, 2009). Mogelijk hebben negatieve ervaringen in het regulier onderwijs hen kopschuw gemaakt. Ook leeftijd speelt een rol. Met name 45-plussers stellen als eis dat het geleerde direct nut heeft en toegepast kan worden in hun eigen situatie. Mogelijk kan 'blended learning' een rol spelen in dit verband. Onder blended learning wordt een combinatie van online onderwijsmateriaal en contactonderwijs verstaan. Het persoonlijk contact met mede-leerders en docenten blijkt een meerwaarde te hebben volgens een aantal informanten. De betrokkenheid met het leertraject neemt toe waardoor men ook meer gemotiveerd is om het gehele traject af te leggen.

2.3 Leven Lang Leren en de rol van begrijpelijke taal Opvallend in het geschetste beeld van LLL is de omvang en de heterogeniteit van de doelgroep enerzijds, en de omvang en de heterogeniteit van het aanbod anderzijds. De doelgroep bestaat immers uit de gehele beroepsbevolking met een grote variabiliteit in vooropleiding, werkervaring, leeftijd en ge- 


\section{De rol van begrijpelijke taal in een digitale context}

letterdheid. Het aanbod van onderwijsinhouden via het Internet neemt razendsnel toe. Die toename heeft zowel een zon- als een schaduwzijde. Door de omvang van het aanbod is de kans groot dat er een inhoud is die uitstekend past bij de specifieke vragen en wensen van individuele leden van de doelgroep maar tegelijkertijd zorgt diezelfde omvang ervoor dat het vinden van juist díe inhoud steeds moeilijker wordt. Een persoonlijk aanbevelingssysteem dat suggesties doet op basis van leerdoel, leerstijl, inhoud en voorkeuren zou hierbij goede diensten kunnen bewijzen (Drachsler, Hummel \& Koper, 2009).

Daarnaast valt op dat het onderwijs binnen LLL sterk afwijkt van het reguliere onderwijs. De informanten schetsen een beeld waarin een gezamenlijk instructie in een lokaal waarbij de lesstof vooral bestaat uit een boek eerder uitzondering dan regel is. LLL vindt plaats waar en wanneer de gebruiker maar wil (al lijkt de huidige generatie werknemers nog steeds de voorkeur te geven aan een rollenspel in in een klaslokaal (Theunissen, 2009)). Bovendien kenmerkt het aanbod zich door multimodaliteit: nog maar zelden bestaat het onderwijsaanbod uit tekst alleen; veel vaker omvat het aanbod geluid en (bewegende) beelden. Bij serious games lijken die elementen zelfs de belangrijkste componenten te vormen. De docent wordt soms vervangen door een virtuele docent die zo levensecht als mogelijk toelichting en instructies geeft of aanzet tot reflectie (Krahmer, 2007; Wouters, Paas \& van Merriënboer, 2009).

Ook al neemt het aandeel van beeld en geluid toe, de rol van taal in LLL blijft essentieel, bijvoorbeeld voor het leggen van de relaties tussen de verschillende informatiebronnen of het aanzetten tot reflectie op het leerproces. De digitale omgeving maakt het mogelijk om taal aan te passen aan individuele kenmerken van de gebruiker. Wat de relevante kenmerken zijn, wordt enerzijds bepaald door de relevante kenmerken van de gebruiker (bv. leesvaardigheid, voorkennis, leerstijl) maar anderzijds ook door de mogelijkheden die het medium biedt (bv. geschreven taal in gesproken vorm aanbieden of - afhankelijk van de leerstijl - informatie talig, visueel of als animatie weergeven). De ontwikkeling van een assessment-instrument dat de relevante kenmerken van de gebruiker in kaart brengt, lijkt daarbij een belangrijke eerste stap.

\section{De burger als consument van complexe financiële producten}

Op 15 maart 2011, de jaarlijkse Wereld Consumenten Dag, startte de Consumentenbond de campagne 'Begrijp je geld?! Weet waar je voor tekent.' De aanleiding is dat burgers financiële producten nodig hebben zoals een hypotheek voor de aanschaf van een huis, een spaarrekening of juist een persoonlijk krediet, maar ook een aansprakelijkheidsverzekering en een pensioen. Recente debacles met woekerpolissen en onnodig dure arbeidsongeschiktheidsen levensverzekeringen met gedwongen huizenverkoop tot gevolg, laten zien dat de aanschaf van dergelijke producten niet zonder risico is. Financiële producten zijn de bekendste, maar zeker niet de enige producten waarbij consumenten er regelmatig pas later achterkomen dat ze een minder geslaagde keuze hebben gemaakt. Dat geldt ook voor het aangaan van een contract bij een aanbieder van mobiele telefonie, een ziektekostenverzekeraar of de afname van gas en stroom bij een energiebedrijf.

Voor het merendeel van deze producten geldt dat er meerdere aanbieders op de markt zijn. De consumenten moeten daarom een keuze maken. De mate waarin consumenten energie willen steken in die evaluatie is volgens Chaiken, Liberman en Eagly (1989) af- 
hankelijk van twee principes: het minste-moeiteprincipe (least effort principle) en het voldoende-zekerheidsprincipe (sufficiency principle). Het eerste principe stelt dat mensen bij voorkeur zo min mogelijk cognitieve energie in de evaluatie willen stoppen. Het voldoendezekerheidsprincipe geeft aan dat afhankelijk van het thema mensen meer of minder zeker willen zijn over het antwoord op de vraag wat het beste alternatief voor hen is. Naarmate de gevolgen belangrijker zijn, zou de gewenste zekerheid toenemen en daarmee ook de bereidheid om meer moeite te doen om de informatie zorgvuldig te evalueren.

Informatie over financiële producten is relatief complex en dat heeft verschillende oorzaken. Eén van die oorzaken wordt gevormd door de complexiteit van het product zelf. Financiële producten zoals hypotheken zijn er in verschillende vormen (bv. spaarhypotheken, beleggingshypotheken en aflossingsvrije hypotheken) die verschillen wat betreft de zekerheid dat de woningschuld is afgelost aan het einde van de looptijd, waarbij aan bepaalde fiscale voorwaarden moet zijn voldaan om optimaal te renderen en waaraan vaak verzekeringen zijn gekoppeld met een lastig te doorgronden kostenstructuur. Waar consumenten vaak focussen op de laagste maandlasten, vergeten ze daarbij soms de lengte van de rentevaste periode of de kosten voor de aan de hypotheek gekoppelde verzekeringen mee te wegen. Bij het afwegen van verschillende alternatieven moet de consument dus relatief veel en ongelijksoortige informatie combineren en afwegen. In verschillende onderzoeken blijkt dat dit een lastige taak is voor mensen (Vlaev, Chater \& Stewart, 2008, 2009). In dit verband is het concept 'financial literacy' van belang, dat wil zeggen "a measure of the degree to which one understands key financial concepts and the ability and confidence to manage personal finances through appropriate, short-term decision-making, and sound long-range financial planning, while mindful of life events and changing economic conditions" (Remund, 2010, p. 284).

Een tweede oorzaak voor de complexiteit komt voort uit de juridische status van de productinformatie. De meest eenduidige informatie over financiële producten staat in de polisvoorwaarden. Deze polis heeft een juridische status en kenmerkt zich dan ook door taalgebruik waarbij eenduidigheid en exactheid zwaarder wegen dan begrijpelijkheid. Voor niet-ingewijden vormt dit taalgebruik een extra barrière om de precieze productkenmerken te doorgronden. Een derde oorzaak, ten slotte, is gelegen in de communicatiestrategie van sommige aanbieders. De recente affaires rond woekerpolissen en risicovolle hypotheken hebben laten zien dat sommige aanbieders onevenwichtig informatie hebben verstrekt over hun producten. Zo werd bij de woekerpolissen vooral geschermd met hoge rendementen maar werd informatie over de mogelijkheid dat deze rendementen niet behaald zouden worden, de restschuld waarmee de consument dan zou blijven zitten en de hoge beheerskosten veel minder prominent besproken. Een vergelijkbare strategie hanteerde de DSB bij de verkoop van hypotheken door de nadruk te leggen op de lage maandlasten maar informatie over de rentevaste periode en de kosten van de eraan gekoppelde verzekeringen minder nadrukkelijk te bespreken.

De publiciteit die bovenstaande affaires met zich mee heeft gebracht, leidde tot meer aandacht voor de rol van de toezichthouders. Zo is er de AFM (Autoriteit Financiële Markten) die in 2002 de Stichting Toezicht Effectenverkeer heeft opgevolgd. De AFM heeft als doel de bevordering van eerlijke en financiële markten. Daartoe controleert ze onder andere of de consument duidelijke en eerlijke informatie krijgt. De SRC (Stichting Reclame Code) richt zich op reclame in het algemeen. Deze stichting wil de betrouwbaarheid en geloofwaardigheid van reclame bevorderen. Identificatie van misleidende reclameboodschappen die de 


\section{De rol van begrijpelijke taal in een digitale context}

consument op het verkeerde been proberen te zetten, vormt daarbij een belangrijk doel. De Consumentenautoriteit (waarover in maart 2011 is besloten dat zij zal fuseren met de NMA en de Opta) houdt toezicht op het voorkomen van schendingen van consumentenrechten en het bevorderen van eerlijke handel tussen bedrijven en consumenten. Deze toezichthouders fungeren als een soort scheidsrechter die kan optreden als de consument de dupe dreigt te worden van onzorgvuldige communicatie.

3.1 Methode Om inzicht te krijgen in de gevolgen van de digitalisering voor de consument van complexe financiële producten zijn verschillende organisaties benaderd waaronder zowel aanbieders als toezichthouders. Uiteindelijk zijn er dertien informanten van acht verschillende organisaties geïnterviewd. Onder de deelnemende organisaties waren verschillende banken, een zorgverzekeraar, een pensioenfonds en toezichthouders van de financiële, consumenten- en reclamemarkt.

De opzet van de (half-gestructureerde) interviews was vergelijkbaar met die in de andere verkenningen. De openingsvraag had betrekking op de gevolgen van de verdergaande digitalisering voor de communicatie rond complexe producten. Vervolgens werd gevraagd naar de verschillende modaliteiten die ingezet zouden worden in die communicatie en in hoeverre er rekening gehouden zou moeten worden met verschillende doelgroepen.

3.2 Resultaten Bijna alle informanten wijzen erop dat als gevolg van digitalisering de hoeveelheid informatie over producten en diensten sterk is toegenomen.Veel informatie die vroeger uitsluitend in brochurevorm beschikbaar was, is nu ook op het Internet beschikbaar. De consument kan deze informatie dus ook buiten kantoor(m)uren raadplegen. Als gevolg van de digitalisering strekt de informatievoorziening zich meer uit in de tijd. Oude informatie over producten is vaak nog beschikbaar terwijl het in vergelijking met vroeger veel gemakkelijker is om informatie te actualiseren waardoor de verschillende versies elkaar snel opvolgen. Ondanks het grote en voor velen toegankelijke informatieaanbod kiezen de aanbieders er bewust voor om dezelfde informatie ook via traditionele kanalen zoals brochures of persoonlijke adviesgesprekken te blijven aanbieden. Dat kan tot gevolg hebben dat een via het Internet beschikbare brochure via printing-on-demand wordt gedrukt en per post naar de potentiële klant gestuurd. De overweging van de aanbieders is dat men zoveel mogelijk tegemoet wil komen aan de wensen en voorkeuren van de consument.

De toename van het aantal kanalen waarlangs informatie wordt aangeboden heeft ook gevolgen voor de vorm van het informatieaanbod. Op basis van hun ervaringen met commerciële websites koesteren consumenten die zich oriënteren op financiële producten via het Internet hoge verwachtingen over het gebruiksgemak en de aantrekkelijkheid van de website. De aanbieders benadrukken dat dit consequenties heeft voor de presentatiewijze. Langere stukken tekst waarbij de consument moet scrollen of klikken proberen ze zoveel mogelijk te vermijden terwijl de inzet van (audio-)visuele elementen toeneemt. Filmpjes worden met name ingezet om huidige gebruikers van een product aan het woord te laten of de consequenties van verschillende keuzes te verbeelden.

Het via verschillende kanalen aanbieden van informatie en de blijvende beschikbaarheid ervan, leidt tot een sterke toename van het informatieaanbod, zeker omdat verschillende aanbieders deze strategie hanteren. Met deze toename, neemt ook de uitdaging wat betreft de selectie en evaluatie van informatie exponentieel toe. Hoe vindt de consument die informatie die gegeven zijn omstandigheden en wensen het meest relevant is? Nog steeds 
bestaat de mogelijkheid tot persoonlijk contact met medewerkers van instellingen die de consumenten kunnen helpen in die zoektocht, maar daarmee verliezen consumenten de mogelijkheid om die informatie waar en wanneer zij willen te raadplegen. De informanten verwachten veel van de zogenaamde avatars, digitale personages die voor een virtueel persoonlijk contact kunnen zorgen.

Bij het gebruik van avatars is het van belang dat deze goed kunnen omgaan met consumentenvragen. Volgens de informanten kunnen veranderingen in de leefsituatie van consumenten daarbij een werkbaar uitgangspunt vormen. Mensen gaan niet zo maar op zoek naar informatie. Ze willen een huis kopen en oriënteren zich daarom op een hypotheek, ze gaan scheiden en willen weten welke consequenties dat heeft voor hun pensioen, ze worden zwanger en willen weten wat dat betekent voor hun verzekering. Deze insteek in informatievoorziening biedt grote voordelen: in plaats van een "alles wat wij u kunnen vertellen over onze hypotheken"-benadering waarbij consumenten ook veel informatie krijgen waarin ze niet geïnteresseerd zijn, is het mogelijk om alleen díe informatie te geven die relevant is voor de consument in zijn of haar situatie. De kans dat de consumenten deze informatie met de benodigde interesse lezen, neemt daarmee toe. Bovendien biedt deze insteek de mogelijkheid om vragen te beantwoorden die de consumenten eigenlijk zouden moeten stellen, maar waarvan ze zich niet bewust zijn.

De bovenstaande strategie heeft betrekking op de selectie van de inhoud maar zegt niets over de begrijpelijkheid ervan. Die begrijpelijkheid hangt enerzijds af van de kenmerken van de tekst maar anderzijds van de bereidheid van de consument om energie te steken in de verwerking van die informatie. De wetgever stelt dat hierbij mag worden uitgegaan van "een gemiddeld geïnformeerde, omzichtige en oplettende consument". In een uitspraak van de rechtbank wordt daarbij opgemerkt dat van een dergelijke consument verwacht mag worden dat hij of zij zich baseert op alle relevante informatie bij het aangaan van een langlopend financieel product. Tegelijkertijd hebben de recente affaires laten zien dat veel consumenten niet aan dit criterium voldoen. De informanten in dit onderzoek spreken van 'low interest' of zelfs 'no interest' waar het financiële producten betreft. Begripsproblemen bij de communicatie rond financiële producten zouden daarom mede het gevolg kunnen zijn van een gebrek aan inspanning aan de kant van de consument.

Volgens de informanten in dit onderzoek worden er geen verschillende versies van polisvoorwaarden of productinformatie ontworpen voor laaggeletterden of mensen met een andere moedertaal. Segmentatie vindt wel op een andere manier plaats. Zo onderscheidt de AFM mensen die meer of minder financieel geletterd zijn. Bij degenen die relatief hoog scoren op financiële geletterdheid, onderscheidt de AFM mensen die ambitieuze financiele doelstellingen hebben en daarom bereid zijn risico's te nemen van mensen die meer "beheerste" keuzes maken. Bij de lager financieel geletterden spreekt men van "adviesgevoeligen" die open staan voor financieel advies en "gemaksgeoriënteerden" die veelal de eerste de beste aanbieding accepteren. Deze segmentatie biedt vooral inzicht in de rol die door aanbieders verstrekte informatie speelt (of vaak: niet speelt) in het afwegingsproces. Men lijkt eerder op zoek naar een soort "begrijpelijkheids"-ondergrens die ook voor deze groepen tot begrijpelijke teksten zou moeten leiden.

3.3 De rol van begrijpelijke taal bij informatie over complexe financiële producten De begrijpelijkheid van boodschappen over financiële producten staat onder druk als gevolg van de juridische status van die informatie en de complexiteit van de producten. Het is dan ook 


\section{De rol van begrijpelijke taal in een digitale context}

niet vreemd dat de nadruk ligt op het zo begrijpelijk mogelijk maken van de communicatie rond die producten. Toch is het de vraag of daar de meeste winst te behalen is. Wettelijk wordt verwacht dat de informatie begrijpelijk moet zijn voor de gemiddeld geïnformeerde, oplettende en omzichtige consument. Aan die verwachting wordt echter zelden voldaan. Het merendeel van de consumenten lijkt nauwelijks geïnteresseerd in het zorgvuldig verwerken van de informatie met als gevolg dat inspanningen om de begrijpelijkheid ervan te verbeteren eigenlijk geen praktische consequenties hebben. In termen van Chaiken et al. (1989): het least effort principle weegt veel zwaarder dan het sufficiency principle.

Stone (2009) wijst erop dat er in de financiële dienstverlening nog onvoldoende gebruik wordt gemaakt van de mogelijkheden die het Internet biedt voor het personaliseren en individualiseren van informatie waarbij de consument alleen díe informatie ontvangt die voor hem of haar relevant is. Een dergelijke strategie zou een positieve invloed kunnen hebben op de motivatie van de consumenten om de productinformatie aandachtiger te verwerken (Kreuter, Strecher \& Glassman, 1999). De door de informanten genoemde strategie om informatie te koppelen aan veranderingen in de levensgebeurtenis lijkt een stap in de goede richting.

Daarnaast biedt het 'financial literacy' concept een mogelijkheid om de communicatie beter toe te snijden op de kenmerken van de doelgroep. Dit concept helpt bij het specificeren van de benodigde inhoudelijke voorkennis en laat ook het belang van gecijferdheid zien. Bij veel financiële producten spelen waarschijnlijkheid en onzekerheid een grote rol. Het afwegen van gevolgen die verschillen in de waarschijnlijkheid waarmee ze optreden én de wenselijkheid van die gevolgen is een complexe vaardigheid waar lang niet iedereen over beschikt maar die wel consequenties heeft bij de evaluatie van informatie (Gibson, Callison \& Zillmann, 2011). Het op begrijpelijke wijze communiceren van dit soort informatie zou een belangrijke stap voorwaarts kunnen vormen.

\section{De burger als partner en cliënt van de overheid}

De Nederlandse overheid en de Nederlandse burger communiceren veel met elkaar. Die communicatie verloopt niet probleemloos. Het gebrek aan begrijpelijke taal geldt als één van de top-10 knelpunten in het dienstverleningsproces aan burgers. Maar de relatie waarin de overheid een dienst levert aan de burger is slechts één van verschillende relaties die de overheid en burger met elkaar onderhouden. In een recent onderzoek (Waarstaatjegemeente. nl) naar de communicatie tussen gemeentes en hun burgers worden de volgende rollen onderscheiden;

- De burger fungeert als partner wanneer de overheid in het kader van beleidsvorming de meningen en ideeën van burgers vraagt voor de analyse van een probleem, de verkenning van de mogelijke oplossingen en het evalueren van die alternatieven. Het betrekken van de burger in het beleidsvormingsproces wordt gezien als een belangrijke strategie om de kloof tussen burger, overheid en politiek te dichten. De burgers fungeren ook als beoordelaars van die overheid en politiek. Bij verkiezingen kunnen ze hun (on)tevredenheid over de gemakkte keuzes uiten in hun stemgedrag.

Geïmplementeerd beleid leidt tot regels en wetten die rechten én plichten met zich meebrengen voor de burger. Dat brengt twee nieuwe rollen met zich mee. 
- Waar het de plichten betreft, fungeert de burger als onderdaan. Hij of zij moet belasting betalen, stoppen voor een rood verkeerslicht en afval in de daarvoor bestemde zakken, op het daarvoor bestemde tijdstip, op de daarvoor bestemde plaats neerzetten.

- Waar het de rechten betreft, fungeert de burger ook als cliënt. Hij of zij heeft recht op kinderbijslag, mag een dakkapel plaatsen of een nieuw paspoort aanvragen.

- Ten slotte is de burger een medegebruiker van de samenleving en de daaraan gekoppelde faciliteiten. De overheid probeert de burger aan te zetten om daar op een verantwoordelijke manier mee om te gaan. Zo voert zij campagnes om de burgers aan te zetten tot veilig en gezond gedrag of tot het nemen van milieusparende maatregelen.

Om als burger de bovenstaande rollen goed te kunnen vervullen, moet hij of zij beschikken over relevante, begrijpelijke en toepasbare informatie. Dat besef is ook bij overheid en politiek doorgedrongen. $\mathrm{Zij}$ hebben met regelmaat en met nadruk de intentie uitgesproken om de burgers goed te informeren over politiek, bestuur, beleid en dienstverlening.

De aard van de uitgewisselde informatie en het communicatieproces verandert als gevolg van de rollen die burger en overheid vervullen. Als de overheid de burger ziet als partner in het meedenken en meebeslissen over beleid, is zij geïnteresseerd in de opinies en beweegredenen van die burger. Zo kan zij ervoor zorg dragen dat publieke middelen doelmatig, doeltreffend en tot tevredenheid van de betrokkenen ingezet worden. Waar het de toepassing van wet- en regelgeving betreft, heeft de overheid vaak informatie nodig van die individuele burger om te bepalen of en in welke mate deze burger recht heeft op een bepaalde overheidsdienst of subsidie, dan wel in welke mate de burger de plicht heeft om bijvoorbeeld belasting te betalen. Dit brengt administratieve lasten voor de burger met zich mee, vaak in de vorm van formulieren die burger moet invullen. Ondanks grote verbeteringen in dat opzicht (zie Jansen \& Lentz, 2008), staan “Ingewikkelde en onbegrijpelijke formulieren" nog steeds in de top 10 van knelpunten in de dienstverlening aan burgers. De overheid spant zich in om deze administratieve lasten zo laag mogelijk te houden en haar diensten zo klantvriendelijk, effectief en efficiënt mogelijk te leveren. In bovenstaande gevallen is er sprake van interactie tussen overheid en burger. Daar waar de overheid het gedrag van haar burgers probeert te beïnvloeden, lijkt die interactie in veel mindere mate aanwezig. De overheid neemt het initiatief om haar burgers duidelijk te maken waarom bepaalde gedragingen wenselijker zijn dan andere.

We spreken over "de" overheid wat een monolithische organisatie suggereert. Niets is minder waar. Onder het label "de" overheid gaan vele verschillende bestuurslagen en organisaties schuil. Zo zijn er 11 ministeries, 12 provincies, 418 gemeentes, 25 waterschappen, 9 uitvoeringsorganisaties zoals de Belastingdienst en de UWV, en talloze organisaties zoals de politie, openbare bibliotheken en GGDs. Elk van deze onderdelen heeft zijn eigen wettelijke grondslag met consequenties voor de doelen die het nastreeft en daardoor ook voor de rolverdeling tussen organisatie en burger. Sommige organisaties hebben een relatief eenduidige relatie met de burger, zoals de Belastingdienst. Een gemeente daarentegen, zit in heel verschillende rollen met haar burgers om de tafel. Ze is geinteresseerd in de voorkeuren van haar inwoners voor de inrichting van de openbare ruimte, maar moet ook de hondenbelasting innen, een besluit nemen over een bouw- of kapvergunning én over het subsidiëren van de straatbarbecue. In de verschillende rollen die de burger krijgt toegedicht, krijgt hij te maken met verschillende tegenspelers in verschillende rollen, maar soms ook met dezelfde tegenspeler die verschillende rollen speelt. 


\section{De rol van begrijpelijke taal in een digitale context}

Huysmans en De Haan (2010) hebben laten zien dat de manier waarop de overheid met haar burgers communiceert sterk is veranderd in de afgelopen decennia. De overheid heeft het Internet en andere digitale toepassingen in haar communicatie met burgers omarmd zowel waar het informeren en consulteren betreft als bij het verlenen van diensten. In deze verkenning, is een aantal van die tegenspelers bevraagd over hun visie in hoeverre die ontwikkelingen zich zullen doorzetten.

4.1 Methode In het onderzoek zijn elf informanten van verschillende organisaties geïnterviewd. Onder die organisaties bevonden zich de rijksoverheid, twee gemeentes, een uitvoeringsinstantie, een organisatie van ambtenaren die nadenken over het Internet als middel om het functioneren van de overheid te verbeteren, de politie en twee politieke partijen. De interviews waren op een vergelijkbare manier opgezet als de interviews in de andere domeinverkenningen.

4.2 Resultaten Voor alle informanten gold dat ze enthousiast waren over de inzet van nieuwe technologieën in de communicatie met burgers. Zij zien vooral goede mogelijkheden om langs meer kanalen met de burger in contact te komen. Dat enthousiasme komt enerzijds voort uit de wens om de burger beter van dienst te kunnen zijn en anderzijds door de mogelijkheid van kostenbesparingen. Voor de burgers biedt een digitaal loket op de gemeentelijke website de mogelijkheid om een vergunningsaanvraag in te dienen op een tijdstip dat hun uitkomt en zonder dat ze daarvoor naar het gemeentehuis hoeven te gaan. Voor de gemeente biedt de afnemende drukte aan de balie de mogelijkheid tot kostenbesparingen.

De aard van de ingezette technologie hangt onder andere af van de rol die de burger heeft. Zo worden sociale media zoals Hyves, Facebook en Twitter vooral ingezet door gemeentes en politieke partijen. Meer nog dan websites bieden deze media de mogelijkheid tot (groeps)interactie. Sociale media hebben in de ogen van de informanten een belangrijke meerwaarde daar waar de burger als partner in het beleid- en besluitvormingsproces wordt beschouwd. Het biedt goede mogelijkheden om burgers in staat te stellen hun ideeën, voorkeuren en beweegredenen te uiten. Dat verklaart ook waarom informanten op het niveau van de rijksoverheid de wens en de verwachting uitspreken dat ook op dat niveau meer gebruik gemaakt zal worden van sociale media.

Daarnaast wordt digitalisering ingezet om de informatie over relevante wet- en regelgeving ter beschikking te stellen en de administratieve lasten voortvloeiend uit de toepassing van deze wet- en regelgeving te verlichten. Zo streven lokale overheden ernaar om de burger via hun website te informeren over de regelgeving rond bouwvergunningen, maar ook om ze in staat te stellen om een aanvraag voor een dergelijke vergunning via diezelfde website in te dienen. De Belastingdienst is een bekend voorbeeld van een uitvoeringsinstantie die op deze manier de administratieve lasten voor de burger probeert te verlagen. Dat doet zij niet alleen door rekenmodules toe te voegen aan haar aangifteformulier maar ook door bijvoorbeeld bij haar bekende gegevens al in te vullen. Hierdoor wordt ook een efficiëntieslag gemakt doordat er minder fouten in de door de burger aangeleverde gegevens staan.

Opvallend is dat alle informanten aangeven dat deze digitale informatie en dienstverlening geen vervanging vormen van de "oude" media maar dat die aanvullend worden ingezet. Naast het digitale aangifteprogramma biedt de Belastingdienst nog altijd de mogelijkheid om met behulp van een schriftelijk formulier aangifte te doen. Brochures met uitleg 
over regelingen zijn nog steeds ook schriftelijk verkrijgbaar. En als burgers geen gebruik willen maken van een webformulier kunnen ze nog altijd telefonisch contact opnemen met de lokale overheid of zich aan de balie melden. De keuze om de nieuwe naast de oude kanalen te laten bestaan, is ingegeven door de overweging dat de digitale communicatiemogelijkheden wellicht een (onoverkoombare) barrière vormen voor de "oudere generatie". Maar niet alleen de overheid blijft gebruikmaken van de "oude" media. Ook de politieke partijen duwen nog steeds folders door brievenbussen en gaan op drukke plaatsen in de stad de discussie aan met voorbijgangers. Behalve het contact met de oudere generatie dat ze anders mogelijk verliezen, denken politieke partijen dat de burger nog steeds behoefte heeft aan rechtstreeks en persoonlijk contact. Bovendien verwachten ze zo informatie te verkrijgen die ze anders zouden missen.

Ook in dit domein speelt het probleem van de vindbaarheid van informatie. Zeker de rijks-, provinciale en lokale overheden zijn op zeer verschillende manieren verbonden met de burger en beschikken daarom ook over veel informatie waarvan de relevantie echter afhankelijk is van de omstandigheden, de wensen en de vragen van de individuele burger. Er zijn verschillende manieren waarop burgers de voor hen relevante informatie kunnen vinden. Ze kunnen navigerend zoeken op de website wat inhoudt dat ze hun zoektocht starten op basis van kopjes, hyperlinks, afbeeldingen en keuzemenu's. Een heldere structuur van de site gekoppeld aan goed gekozen formuleringen voor de thema's moet ervoor zorgen dat mensen niet de weg kwijt raken in de site. Vaak bieden sites ook de mogelijkheid om zoektermen in te voeren in een zoekmachine en/of een vraag te stellen aan een virtuele medewerker. Zoals verschillende informanten opmerken is ook dat geen garantie voor succes. Vaak is er nogal wat voorkennis over het thema nodig voor de formulering van geschikte zoektermen of een relevante vraag. De overheid kiest in sommige gevallen om de informatie te ordenen rond concretere situaties, aangeduid als 'levensgebeurtenissen', zoals een site waarin alle informatie voor scholieren en studenten over bijverdienen van verschillende instanties bij elkaar is gebracht.

De informanten zijn zonder uitzondering enthousiast over de mogelijkheden om talige informatie aan te vullen met beeld en geluid. Multimodaliteit is eerder de norm dan de uitzondering. Tegelijkertijd vertellen veel informanten in het duister te tasten over hoe de optimale multimodale combinatie eruit ziet. Zij worstelen met vragen over wanneer het beeld een goede vervanger is voor de tekst en wanneer het omgekeerde geldt. Zij zijn er wel van overtuigd dat voor een optimaal gebruik van het digitale medium, het taalgebruik aangepast dient te worden. Dat geldt niet alleen voor het taalgebruik bij sociale media, maar ook bij de informatie die via websites wordt aangeboden. Volgens veel informanten moet de informatie korter, directer en concreter worden aangeboden. Hun inschatting is dat er meer gebruik gemaakt wordt van opsommingen, korte stukken tekst waarvan het thema door een kopje wordt gesignaleerd en die door middel van hyperlinks met elkaar verbonden zijn.

Digitalisering biedt mogelijkheden voor het aanpassen van informatie aan de gebruiker. De informanten denken daarbij in eerste instantie aan het personaliseren van informatie: de naam van de gebruiker in de communicatie gebruiken en bij formulieren eventueel bekende informatie (adres, etc.) al invullen. Hoewel men zich zegt te realiseren dat verschillende doelgroepen (bijvoorbeeld laaggeletterden) een andere benadering vereisen, streeft men ernaar dat de verstrekte informatie voor iedereen begrijpelijk moet zijn. Daarbij gaat men uit van een "gemiddelde burger" waarbij onduidelijk is wat de kenmerken van die gemiddelde burger zijn. 
4.3 De rol van begrijpelijke taal in de relatie tussen burger en overheid De overheid heeft de mogelijkheden die de digitale media bieden nadrukkelijk omarmd zonder afstand te doen van de oude media. Men gebruikt sociale media om de burger bij de beleids- en besluitvorming te betrekken en probeert door personalisering de dienstverlening te verbeteren en de administratieve lasten te verlichten. Met name op het terrein van begrijpelijke formulieren boekt men vooruitgang. Websites spelen, als informatiebron én als dienstverleningskanaal, een belangrijke rol in dit proces.

De informanten maken zich ook zorgen. Die zorgen hebben deels betrekking op de vindbaarheid van informatie. Juist omdat de overheid via zoveel verschillende dossiers met de burger is verbonden, beschikt ze over een enorme hoeveelheid informatie die vaak maar voor een klein deel van de doelgroep relevant is. Een belangrijke uitdaging is ervoor te zorgen dat de burger precies die informatie krijgt die in zijn of haar situatie relevant is. Daarnaast vragen de informanten zich af hoe ze de multimodale mogelijkheden het beste in kunnen zetten: welke informatie leent zich het beste voor (bewegende) beelden, welke informatie kan het beste talig worden gepresenteerd en in hoeverre hangt het antwoord op deze vragen af van de eigenschappen en voorkeuren van de doelgroep? De mogelijkheden die digitale media bieden om de boodschap aan te passen aan de kenmerken van de doelgroep worden wat betreft de begrijpelijkheid van de boodschap nauwelijks gebruikt. De insteek lijkt eerder om een soort gouden standaard voor begrijpelijkheid te ontwikkelen.

\section{De burger als patiënt}

Wie vraagt naar de toekomst van de gezondheidszorg, komt onvermijdelijk binnen de kortste keren terecht bij begrippen als "eHealth", "mHealth", "telemedicine", en "Gezondheid 2.0". Uit dergelijke benamingen wordt al duidelijk dat hier een grote rol is weggelegd voor informatie- en communicatietechnologie in de zorg. De beloften van deze technische oplossingen zijn groot: ze zouden de zorg betaalbaar, toegankelijk en - ondanks de technologische insteek - menselijk houden. Over wat deze ontwikkelingen kunnen betekenen, is al veel geschreven waarbij de nadruk veelal ligt op de verschuivende verhoudingen tussen de betrokkenen, op de kostenbesparingen en hoe die bewerkstelligd kunnen worden, en op technische aspecten en uitdagingen die nog open liggen (zie bijvoorbeeld het in opdracht van de Europese Commissie geschreven rapport van Stroetman, Jones, Dobrev \& Stroetman, 2006) en over de wijze waarop de potentie van eHealth in sterkere mate gerealiseerd kan worden (Bennett \& Glasgow, 2009). Tegelijkertijd zetten Black, Car, Pagilari, Anandan, Cresswell et al. (2011) grote vraagtekens bij de mate waarin er evidentie is voor de alom geroemde zegeningen die eHealth met zich mee zou brengen (waarbij zij zich vooral hebben gericht op het onderzoek naar elektronische patiëntdossiers en naar computerondersteunde besluitvorming door medisch personeel).

Eén van de terugkerende thema's bij de implicaties van eHealth vormt de rol van de patiënt: deze zou dankzij de nieuwe ontwikkelingen zelfstandiger en geëmancipeerder worden en meer verantwoordelijkheid krijgen. "Meer eigen verantwoordelijkheid en zelfstandigheid" voor de patiënt klinkt als een positieve ontwikkeling, maar het roept tevens vragen op. Hoe komt een patiënt aan voldoende kennis om deze verantwoordelijkheid te kunnen dragen? Waarop baseert hij of zij de keuzes die gemaakt moeten worden in het zorgproces, en hoe komt het vertrouwen in de zelfstandig gemaakte keuzes tot stand? Een belangrijk 
concept in dit verband is 'gezondheidsgeletterdheid' (health literacy). Berkman, Davis en McCormack (2010, p. 16) definiëren gezondheidsgeletterdheid als "The degree to which individuals can obtain, process, understand, and communicate about health-related information needed to make informed health decisions". Berkman et al. komen tot deze definitie na het geven van een overzicht over hoe het concept geletterdheid zich in de Verenigde Staten in de afgelopen twee eeuwen heeft ontwikkeld van het antwoord op de vraag "kunt u - in welke taal dan ook - lezen en schrijven" (die in eerste instantie alleen aan blanke, volwassen mannen werd gesteld) tot het concept "functional competence" waarin naast taalvaardigheid ook informatieverwerking, probleemoplossen, werkgeheugencapaciteit en numerieke vaardigheden werden meegenomen. Dit concept moest een beeld geven van de mate waarin mensen over de vaardigheden beschikten om op hun werk en in de samenleving te kunnen functioneren, hun doelen te realiseren, kennis te verwerven en hun talenten te realiseren. Gezondheidsgeletterdheid betreft dus de vaardigheden waarover mensen moeten beschikken om beredeneerde keuzes te kunnen maken met betrekking tot hun gezondheid.

Verschillen in gezondheidsgeletterdheid worden vaak in verband gebracht met de kloof tussen gezonde en minder gezonde mensen, een kloof die tevens gekenmerkt wordt door een verschil in Sociaal economische status (SES). Viswanath en Kreuter (2007) wijzen op het gevaar dat de gezondheidskloof tussen mensen met een hogere SES en mensen met een lagere SES zich zal verbreden en verdiepen als niet rekening wordt gehouden met de verschillen in de toegang tot gezondheidsinformatie en in het vermogen om die informatie te begrijpen. Zo verwijzen ze naar onderzoek dat laat zien dat de begrijpelijkheid van de informatie op veel Amerikaanse websites de capaciteiten van een groot deel van de bevolking te boven gaat (zie, bv. Berland, Elliott, Morales, et al., 2001; Van Deursen, 2010). In deze verkenning staat de vraag centraal hoe de daarvoor noodzakelijke informatievoorziening er in het digitale tijdperk uitziet en hoe die communicatie alle mensen in staat kan stellen om op verantwoorde wijze beslissingen over de eigen gezondheid te nemen.

5.1 Methode De belangrijkste spelers in de gezondheidszorg worden wel beschreven als de drie P's: de patiënt, de professional (bv. de arts) en de "payer" (bv. de zorgverzekeraar). Er zijn interviews gehouden met professionals die werkzaam zijn bij ziekenhuizen en GGD. Ook is gesproken met informanten die verbonden zijn aan zorgverzekeraars, met vertegenwoordigers van een patiëntenvereniging, met de verantwoordelijken voor een grote overheidswebsite over gezondheid en met een ondernemer op het gebied van ICT-toepassingen in de gezondheidszorg. Ten slotte zijn er gesprekken gevoerd met twee vooraanstaande Amerikaanse onderzoekers op het terrein van Tailored Health Communication. In totaal werden er elf interviews gehouden.

5.2 Resultaten Het eerste punt dat bij vrijwel alle interviews naar voren kwam, is dat communicatie nog vaak verloopt via de traditionele kanalen: patiënten spreken hun huisarts of specialist in de spreekkamer of via de telefoon, informatie wordt gedeeld via folders, en websites bevatten dezelfde statische pagina's en formulieren als hun papieren equivalent en fungeren soms vooral als een digitaal folderrek. De redenen achter deze terughoudendheid wordt op verschillende manieren geduid, variërend van gebrek aan tijd en geld tot onwetendheid en angst voor het onbekende.

De informanten zijn er echter van overtuigd dat er een verandering op handen is.Vooral vanuit de patiënt- en consumentenkant is er een grote behoefte ontstaan aan nieuwe, in- 


\section{De rol van begrijpelijke taal in een digitale context}

teractieve en vooral méér communicatie. Er is een ontwikkeling gaande waarbij de patiënt verandert van een passieve luisteraar naar een zorgconsument die actief deelneemt aan zijn of haar behandeling en die daarbij als volwaardig gesprekspartner aan het communicatieproces wil deelnemen. In 2008 bleek uit een onderzoek van TNS NIPO dat ruim 7 op de 10 Nederlanders bij het betreden van de spreekkamer van de huisarts al een idee hadden van de ziekte of aandoening die ze zouden kunnen hebben.Via Google, maar ook via vrienden en kennissen, proberen mensen zelf al tot een diagnose te komen over wat ze mankeren. Hoewel huisartsen wijzen op de potentiële gevaren van zelfdiagnose, illustreren deze cijfers een onomkeerbare trend in de gezondheidszorg: patiënten zien hun arts niet (meer) als enige of primaire bron van informatie.

Het bovenstaande geldt voor mensen die over het algemeen gezond zijn en slechts incidenteel naar de huisarts gaan, maar in nog sterkere mate voor patiënten met een chronische of langdurige aandoening. Juist deze patiënten gaan op internet op zoek naar informatie over behandelingen en vooruitzichten, maar ook over hoe om te gaan met hun aandoening. De ervaring van vrijwel alle geïnterviewde experts is dat voor deze groep patiënten de klassieke folder van de huisarts of het ziekenhuis niet meer voldoende is. Ook uit onderzoek is gebleken dat vooral mensen met een chronische aandoening gebruik maken van het internet om informatie over hun aandoening te vinden (Bundorf, Wagner, Singer \& Baker, 2006). Aangezien er steeds meer chronisch zieken zullen komen, door de toename van welvaartsziekten en de vergrijzing, en doordat voorheen dodelijke aandoeningen beter behandeld kunnen worden, is de verwachting dat er ook steeds meer mensen het internet op zullen gaan om informatie te zoeken.

Niet voor iedereen geldt dat men actief bezig is met zijn of haar gezondheid.Vooral de experts uit de zorgpreventie wijzen er op dat mensen die niet het idee hebben dat ze een bepaald risico lopen, communicatie die hen daarop wijst negeren. De ervaring leert bijvoorbeeld dat mensen die van hun huisarts horen dat ze diabetes 2 hebben, vaak niet geneigd zijn om zich te verdiepen in de consequenties hiervan omdat vooral onder de oudere generatie de opvatting heerst "dat dat er nu eenmaal bij hoort vanaf een bepaalde leeftijd". Dit illustreert dat de actieve zorgconsument alleen bestaat wanneer mensen zelf iets als een probleem ervaren. De groep die zelf geen probleem ervaart, blijft, ook met de digitale communicatietechnieken, moeilijk te bereiken. Voor toekomstig onderzoek ligt hier dan ook de uitdaging om mensen die niet het idee hebben dat ze informatie nodig hebben, toch te interesseren in die informatie. Daarnaast zijn er mensen die niet (meer) in staat zijn om mee te gaan in de digitale ontwikkelingen zoals computers en internet. Sommige geïnterviewden waarschuwen voor de kloof die kan ontstaan tussen de digitaal vaardige en de digitaal minder vaardige patiënt: er zal een nieuwe vorm van analfabetisme ontstaan.

De grote groep patiënten die wel in staat en gemotiveerd is om actief op zoek te gaan naar informatie, zoekt deze informatie vooral online. Door het gebruik van (suboptimale) zoekstrategieën levert dat een zeer groot aantal zoekresultaten op, waardoor het moeilijk wordt om de meest relevante informatie te selecteren. Dat wordt volgens de geïnterviewden mede veroorzaakt doordat mensen tijdens het zoeken naar informatie slechts vluchtig lezen. Door de hoeveelheid aan informatie is het onmogelijk om alles grondig te lezen, maar ook als iemand eenmaal op een bepaalde website is aangekomen blijken lange stukken tekst al snel te veel. Slechts in sommige gevallen zet men systematisch alles op een rijtje om op basis daarvan een gefundeerde keuze te maken, maar meestal is de eerste "goed genoeg" optie al het eindpunt van de zoeksessie (zie, voor een overzicht, Tiemeijer, Thomas \& Prast, 2009). 
Eysenbach en Köhler (2002) hebben laten zien dat mensen wel vaak aangeven dat ze het belangrijk vinden dat de informatie betrouwbaar is, maar dat men in de praktijk nauwelijks let op de betrouwbaarheid van de afzender. Ook zijn slechts weinigen bekend met een keurmerk als het 'HON' (van de Health on the Net Foundation, www.hon.ch), dat garandeert dat de maker van de site een medisch professional is en dat de site aan diverse strenge betrouwbaarheidseisen voldoet. Patiënten blijken vooral vertrouwen te hebben in hun medepatiënten. Sites van lotgenootgroepen, weblogs, patiëntenverenigingen en sociale media zoals Twitter en Facebook nemen een essentiële plaats in bij de communicatie over gezondheid (Engelen, 2010). Men gebruikt dergelijke bronnen vooral om zich te oriënteren op een onderwerp en als wegwijzer naar andere informatiebronnen. Eysenbach (2008) spreekt hierbij over 'apomediatie': apomediairs bieden vooral meta-informatie en ondersteuning bij het zelf selecteren van de informatie. Apomediairs kunnen medepatiënten of familieleden zijn, maar ook anonieme anderen. Social bookmarking is een ander voorbeeld van de wijze waarop gebruikers verwijzingen naar internetsites kunnen voorzien van tags (labels) waar andere gebruikers in kunnen zoeken.

Vrijwel alle experts geven aan dat er belangrijke winst te behalen is bij het ondersteunen van het zoek- en selectieproces. Vergelijkbaar met "Google Ads", waarbij een computergebruiker alleen advertenties te zien krijgt die aansluiten bij zijn of haar interesses, zouden zoeksystemen in staat moeten zijn om achtergrondinformatie van de gebruiker mee te nemen in de selectie van informatie. Met kennis uit de informatiekunde zou het in de nabije toekomst mogelijk moeten zijn om computers te voorzien van "intelligentie" die kan helpen bij het selecteren van de juiste bronnen. Sommige experts gaan zelfs zo ver dat ze een toekomstbeeld schetsen waarin dit proces voor een deel automatisch gaat: op basis van de omstandigheden zou een individu van op dat moment relevante informatie voorzien kunnen worden. De ethische en privacygerelateerde aspecten van een dergelijk systeem daargelaten, zou dit het verzamelen en selecteren van informatie voor de consument of patiënt een stuk eenvoudiger maken.

Dat patiënten hun informatie vooral zoeken binnen 'peer' groepen en sociale media is volgens sommige geïnterviewden ook het gevolg van de relatieve onbruikbaarheid van veel informatie op het Internet. Informatie van officiële bronnen is over het algemeen statisch, en te algemeen of juist te specifiek voor de gemiddelde patiënt. Daarnaast is officiële medische informatie zowel wat inhoud als stijl betreft vaak erg complex (zie Friedman, HoffmanGoetz \& Arocha, 2006). Om aan de groeiende behoefte om toch kennis te nemen van deze informatie te voldoen, zijn initiatieven ontstaan om deze informatie toegankelijker te maken. Zo werkt het Diabetesfonds mee aan de website www.leesbaaronderzoek.nl, waarop "de nieuwste medische inzichten in eenvoudige taal" worden samengevat. Ook wordt er door onderzoeksinstellingen en commerciële bedrijven gewerkt aan semantische tools waarmee lange en complexe teksten vertaald kunnen worden naar een samenvatting in "normale" taal. Hier lijkt, net als bij het aanbieden van relevante informatie, wederom een rol weggelegd voor kunstmatige intelligentie en automatische systemen die kunnen helpen met het begrijpelijk en overzichtelijk maken van informatie.

Het toesnijden op de doelgroep met behulp van ict heeft met name in de gezondheidscommunicatie een grote vlucht genomen sinds de monografie van Kreuter, Farrell, Olevitch en Brennan (2000) over Tailored Health Communication. Bij Tailored Health Communication wordt de boodschap toegesneden op individuele kenmerken en voorkeuren die middels een assessment zijn vastgesteld. Daarbij wordt aandacht besteed aan de inhoud van de 


\section{De rol van begrijpelijke taal in een digitale context}

boodschap - welke informatie is voor dit individu op dit moment relevant - maar ook aan de vorm van de boodschap (voor welke benadering is dit individu gevoelig?) en het kanaal waarlangs dat individu het gemakkelijkste te bereiken is. Noar, Benac en Harris (2007) hebben een meta-analyse uitgevoerd waaruit naar voren komt dat op maat gesneden communicatie inderdaad effectiever is dan meer generieke communicatie maar waaruit ook blijkt de grootte van het effect op gedragsverandering $(r=.074)$ relatief beperkt is.

De Amerikaanse onderzoekers op dit terrein gaven verschillende voorbeelden hoe ze deze strategie toepassen om doorgaans moeilijk bereikbare doelgroepen te achterhalen. Zo worden er in wasserettes in achterstandswijken informatiekiosken geplaatst om vrouwen aan te zetten tot het uitvoeren van een borstkankerscreening. Door middel van een eenvoudige touch-screen interface kunnen de vrouwen, die vaak behoren tot etnische minderheidsgroeperingen die moeilijk te bereiken zijn door de reguliere gezondheidscommunicatie, antwoord geven op een korte vragenlijst waarna de machine ter plekke en persoonlijke folder voor hen afdrukt. De informatie in deze folder speelt in op de individuele factoren die iemand weerhouden van het uitvoeren van de screening, zoals de angsten en barrières die iemand ervaart. In andere projecten wordt er gebruik gemaakt van telefonische vragenlijsten om iemands persoonlijke barrières en overwegingen te achterhalen, waarna die persoon een informatiemap thuisgestuurd krijgt met een op maat gesneden brochure en bijvoorbeeld een koelkastmagneet en een ballpoint met persoonlijke reminders.

5.3 De rol van begrijpelijke taal in gezondheidscommunicatie De informanten in dit domein schetsen twee radicaal verschillende doelgroepen. Enerzijds zijn er de mensen die een gezondheidsprobleem ervaren en als gevolg daarvan actief op zoek gaan naar informatie over hun aandoening. Mede als gevolg van gebrekkige zoekstrategieën wordt deze groep geconfronteerd met een baaierd aan informatie waarbij de selectie van informatie, naast de (geringe) begrijpelijkheid en toepasbaarheid van die informatie, een struikelblok vormt. Als gevolg daarvan zoeken velen hun heil bij lotgenoten via sociale media. Daarmee is het begrijpelijkheidsprobleem vaak opgelost, maar neemt ook het gevaar van beslissingen gefundeerd op onvolledige en onjuiste informatie toe. Anderzijds zijn er mensen die risico lopen op een gezondheidsprobleem maar zich daar onvoldoende van bewust lijken en in elk geval niet geïnteresseerd zijn in dat risico en de mogelijkheden die ze hebben om het probleem te voorkomen. Waar bij de eerste groep de capaciteit om relevante informatie te vinden en te begrijpen het probleem vormt, vormt bij de tweede groep het gebrek aan motivatie om die informatie te verwerken het grootste probleem.

Binnen de gezondheidscommunicatie bestaat wel al veel ervaring in het met behulp van computertechnologie toesnijden van de communicatie op de kenmerken van de individuele ontvanger. Het onderzoek naar deze vorm van communicatie laat zien dat een dergelijke strategie (in bescheiden mate) de effectiviteit van de communicatie kan versterken. Effectiviteit wordt daarbij vooral gemeten in de vorm van de gewenste gedragsverandering. Wellicht dat de effectiviteit van deze strategie voor het vergroten van de begrijpelijkheid sterker werkt. Immers, zoals door Berkman et al. (2010) betoogd, het gaat erom dat het individu een beslissing neemt op basis van de relevante informatie. Het kan gebeuren dat dat individu een andere beslissing neemt dan de gezondheidsprofessional zou willen, maar als die beslissing gebaseerd is op volledige en correcte informatie, moet die beslissing worden gerespecteerd. 
De verdergaande digitalisering en de opkomst van het Internet heeft op alle domeinen geleid tot een enorme toename van het informatieaanbod. Het aanvankelijk optimisme dat door die toename de kenniskloof tussen arm en rijk, laag- en hoogopgeleid, gezond en ongezond, zou worden gedempt, heeft plaats gemaakt voor een pessimistischer beeld (bv., Smith \& Royne, 2010). Het merendeel van de informanten in de verschillende domeinen deelt dat beeld. Weliswaar is door de toename van het informatieaanbod de kans gestegen om actuele, accurate, en relevante informatie te vergaren, maar het lijkt er op dat vooral de rijke, hoogopgeleide burger erin slaagt die informatie te vinden en te gebruiken waardoor de breedte en de diepte van de kloof eerder toe- dan afneemt (Van Deursen \& Van Dijk, 2011).

Een deel van het probleem ligt in het gebrek an motivatie bij de burger. Zelfs als Dick Bruna de polisvoorwaarden zou schrijven, blijven ze ongelezen, is de heersende gedachte. En ook in de gezondheidspreventie bestaat frustratie over het gebrek aan aandacht van mensen voor informatie die kan helpen om toekomstige gezondheidsproblemen te voorkomen. Als mensen wel gemotiveerd zijn om zich te oriënteren, dan worden ze overspoeld met zoveel informatiebronnen dat het praktisch onmogelijk is om het kaf van het koren te scheiden. Als gevolg daarvan nemen ze óf genoegen met de eerste de beste site die hun vraag lijkt te beantwoorden, óf nemen ze hun toevlucht tot sociale media om met hulp van mensen die in hetzelfde schuitje zitten de voor hen relevante informatie te vinden. Het voordeel is dat men relatief anoniem mogelijk "domme" vragen kan stellen aan mensen met ervaringskennis die ook nog dezelfde taal spreken. De kans op het vinden van relevante informatie neemt daarmee toe, net als het risico dat die informatie achterhaald of incorrect is.

De burger is verwend door het professionele design van commerciële sites waarin op aantrekkelijke wijze (bewegend) beeld, geluid en tekst worden gecombineerd. De informanten wijzen op het belang en de wens om de informatie zo aantrekkelijk en helder mogelijk te presenteren waarbij multimodaliteit eerder de norm dan de uitzondering is. Wel leven er veel vragen over welke informatie het beste talig en welke het beste in beeld verpakt kan worden en in hoeverre het antwoord op die vraag afhankelijk is van bepaalde persoonlijkheidskenmerken en voorkeuren van de burger.

De nadruk die informanten leggen op het gebrek aan motivatie bij de ontvanger en het belang van multimodaliteit roept de vraag op hoe belangrijk "begrijpelijke" taal eigenlijk is. Tijdens de interviews bleek het geen thema waar de respondenten zonder aansporing een helder betoog over konden houden. Zoals opgemerkt door één van de reviewers van dit artikel is dat mogelijk het gevolg van de keuze van de informanten. Het betrof met name informanten met veel ervaring met, en een sterk geloof in, de mogelijkheden die verdergaande digitalisering biedt. Die onderschatten wellicht het belang dat de consument hecht aan bijvoorbeeld het persoonlijk adviesgesprek als het om een hypotheek gaat of een studieboek bij het leerproces, en de rol die taal speelt in dergelijke contexten. Naast onderschatting van de rol, lijken ook de verwachtingen over de begrijpelijkheid van bijvoorbeeld polisvoorwaarden, gezondheidsinformatie of informatie over overheidsregelingen niet erg hoog gespannen. Toch geldt voor een belangrijk deel van deze informatie dat die niet gemakkelijk te visualiseren zal zijn. Een daadwerkelijk in begrijpelijkere taal gestelde boodschap vergroot daarmee niet alleen de effectiviteit van het communicatieproces, maar zal gezien de lage verwachtingen die men koestert over begrijpelijkheid ook opvallen. Daarvoor is wel van belang dat het verschil in begrijpelijkheid duidelijk merkbaar moet zijn voor de verschillende doelgroepen. 


\section{De rol van begrijpelijke taal in een digitale context}

Voor het bereiken van dit doel komen we bij de kansen die digitalisering en het Internet bieden: het toesnijden van de inhoud én de vorm op de persoonlijke kenmerken en voorkeuren van de individuele burger kan de begrijpelijkheid en relevantie van die informatie vergroten. Zeker in de gezondheidscommunicatie is er al veel kennis vergaard over de mogelijkheden en positieve effecten van een dergelijke communicatiestrategie. De communicatiestrategie van sommige overheden en financiële dienstverleners om de informatievoorziening te koppelen aan veranderingen in de leef- en woonsituatie van de burger, is een voorbeeld hoe ook in dergelijke domeinen de relevantie van de informatie kan worden verhoogd. Concluderend kunnen we zeggen dat de huidige informatie-explosie op het Internet de potentie heeft om elke burger in staat te stellen om gefundeerde beslissingen te nemen op belangrijke domeinen in het leven en daarmee de kloof tussen haves en de have-nots te verkleinen. Om die potentie te realiseren, is kennis nodig om ervoor te zorgen dat die burger (1) de voor hem of haar relevante informatie vindt en (2) die informatie in de voor hem of haar meest geschikte vorm wordt aangeboden. Het vergaren van die kennis vormt een even wetenschappelijk interessante als maatschappelijk urgente onderzoeksagenda.

\section{Noot}

1 Dit artikel is tot stand gekomen met steun vanuit het NWO-onderzoeksprogramma Begrijpelijke Taal: Fundamenten en toepassingen van effectieve communicatie - project nr.321-70-051.

\section{Bibliografie}

Barbour, M. K., \& Reeves, T. C. (2009). The reality of virtual schools: A review of the literature. Computers $\mathcal{E}$ Education, 52, 402-416.

Bennett, G. G., \& Glasgow, R. E. (2009). The delivery of public health via the Internet:Actualizing their potential. Annual Review of Public Health, 30, 273-292.

Berland, G. K., Elliott, M. N., Morales, L. S., et al. (2001). Health information on the Internet:Accessibility, quality, and readability in English and Spanish. The Journal of the American Medical Association, 285(20), 2612-2621.

Berkman, N. D., Davis, T. C., \& McCormack, L. (2010). Health literacy: What is it? Journal of Health Communication, 15, 9-19.

Black, A. D., Car, J., Pagliari, C., Anandan, C., Cresswell, K., Bokun, T., McKinstry, B., Procter, R., Majeed, A., \& Sheik, A. (2011). The impact of eHealth on the quality and safety of health care: A systematic overview. PLoS Medicine, 8(1): e1000387. Doi:101371/journal.pmed.1000387

Bundorf, M. K., Wagner, T. H., Singer, S. J., \& Baker, L. C. (2006). Who searches the Internet for health information? Health services research, 41, 819-836.

Chaiken, S., Liberman, A., \& Eagly, A. H. (1989). Heuristic and systematic information processing within and beyond the persuasion context. In J. S. Uleman \& J. A. Bargh (Red.), Unintended thought (pp. 212-252). New York: Guilford Press.

Commission of the European Communities. (2000). Commission staff working paper. A memorandum on lifelong learning. Brussels: European Commission.

Deursen van, A.J.A.M. (2010). Internet skills, vital assets in an information society (Doctoral dissertation). Enschede: University of Twente.

Deursen van,A.J.A.M. \& Dijk, van, J.A.G.M. (2011). Internet skills and the digital divide. New Media E Society. DOI: $10.1177 / 1461444810386774$. 
Drachsler, H., Hummel, H. G. K., \& Koper, R. (2008). Personal recommender systems for learners in lifelong learning networks: The requirements, techniques and model. International Journal of Learning Technology, 3(4), 404-423.

Engelen, L. (2010). Een heel klein boekje over Zorg 2.0. Delft: Eburon Uitgeverij BV.

Eysenbach, G. (2008). Medicine 2.0: social networking, collaboration, participation, apomediation, and openness. Journal of Medical Internet Research, 10(3): e22.

Eysenbach, G., \& Köhler, C. (2002). How do consumers search for and appraise health information on the world wide web? Qualitative study using focus groups, usability tests, and in-depth interviews. British Medical Journal, 324(7337), 573-577.

Friedman, D. B., Hoffman-Goetz, L., \& Arocha, J. F. (2006). Health literacy and the World Wide Web: Comparing the readability of leading incident cancers on the Internet. Informatics for Health and Social Care, 31(1), 67-87.

Gibson, R., \& Callison, C., \& Zillmann, D. (2011). Quantitative literacy and affective reactivity in processing statistical information and case histories in the news. Media Psychology, 14, 96-120.

Huysmans, F.,\& De Haan, J. (2010). Alle kanalen staan open: De digitalisering van mediagebruik. Den Haag: Sociaal en Cultureel Planbureau.

Jansen, C., \& Lentz, L. (2008). Formulieren in Nederland. Tijdschrift voor Taalbeheersing, 30, 288-306.

Krahmer, E. (2007). Mens en computer: De menselijke kant van digitale media. Oratie uitgesproken aan de Universiteit van Tilburg.

Kreuter, M., Farrell, D, Olevitch, L., \& Brennan, L. (2000). Tailoring health messages: Customizing communication with computer technology. Mahwah, NJ: Erlbaum.

Kreuter, M.W., Strecher,V.J., \& Glassman, B. (1999). One size does not fit all:The case for tailoring print materials. Annals of Behavioral Medicine, 21, 276-283.

Merriënboer, van, J., Kirschner, P., Paas, F., Sloep, P., \& Caniëls, M. (2009). Towards an integrated approach for research on lifelong learning. Educational Technology Magazine, 49(3), 3-14.

Noar, S. M., Benac, C. N., \& Harris, M. S. (2007). Does tailoring matter? Meta-analytic review of tailored print health behavior change interventions. Psychological Bulletin, 133, 673-693.

Remund, D. L. (2010). Financial literacy explicated:The case for a clearer definition in an increasingly complex economy. The Journal of Consumer Affairs, 44, 276-295.

Smith, R., \& Royne, M. B. (2010). Consumer literacy for credence services: Helping the invisible hand. The Journal of Consumer Affairs, 44(3), 598-606.

Stone, M. (2009). Staying customer-focused and trusted:Web 2.0 and Customer 2.0 in financial services. Database Marketing and Customer Strategy Management, 16(2), 101-131.

Stroetmann, K. A., Jones, T., Dobrev, A., Stroetmann, V. N. (2006). eHealth is worth it: The economic benefits of implemented eHealth solutions at ten European Sites. Luxemburg: Office for Official Publications of the European Communities.

Tiemeijer,W.L., Thomas, C.A., \& Prast, H. M. (Red.) (2009). De menselijke beslisser: De psychologie van keuze en gedrag. Amsterdam:Amsterdam University Press.

Theunissen,N. (2009). Altijd en overal leren: kan het al? In A. ten Brummelhuis, E.M. van Amerongen (Red.), "Hier heb ik niets aan!” Essays over bruikbaar digitaal leermateriaal (pp.171-174). Zoetermeer: Kennisnet.

Viswanath, K., \& Kreuter, M. (2007). Health disparities, communication inequalities, and eHealth. American Journal of Preventive Medicine, 32(5S), S131-S133.

Vlaev, I., Chater, N., \& Stewart, N. (2008). Seeing is not enough: Manipulating choice options causes focusing and preference change in multiattribute risky decision-making. Journal of Behavioral Decision Making, 21, 556-574.

Vlaev, I., Chater, N., \& Stewart, N. (2009). Dimensionality of risk perception: Factors affecting consumer understanding and evaluation of financial risk. The Journal of Behavioral Finance, 9,132-148.

Wouters, P., Paas, F., \& Merrénboer, van, J. J. G. (2009). Observational learning from animated models: Effects of modality and reflection on transfer. Contemporary Educational Psychology, 34(1), 1-8. 